\title{
Autoimmune enteropathy and colitis: is there a generalised autoimmune gut disorder?
}

\author{
S M Hill, P J Milla, G F Bottazzo, R Mirakian
}

\begin{abstract}
Children with protracted diarrhoea, circulating enterocyte autoantibodies, and an enteropathy showing features of inappropriate HLA molecule expression on the jejunal crypt epithelium, often present with persistent blood and mucus in their stools. Eight children with autoimmune enteropathy were investigated for the presence of associated colonic disease. Six children with protracted diarrhoea, no circulating autoantibodies, and an enteropathy (in five of them) undergoing colonoscopy were used as control subjects. In all eight patients, but not in the control subjects, there was macroscopic and microscopic evidence of an accompanying colitis of variable severity, thus indicating that a more generalised intestinal disorder was present, which might affect the whole intestine. Aberrant expression of DR molecules on the colonic surface and crypt epithelium was also detected. Autoimmunity may play a role in the colitis.
\end{abstract}

A proportion of children with protracted diarrhoea associated with an enteropathy have a strong family or personal history or both, of autoimmune diseases, organ and non-organ specific autoantibodies, and persistent circulating enterocyte autoantibodies, thus suggesting that autoimmunity may play a role in the enteropathy.' We have previously reported that the enterocyte autoantibodies seem to be virtually specific to this condition in that they were not detected in sera from children with coeliac disease and were present only in lower titres (less than $1 / 8$ ) in $5 \%$ of patients with classic inflammatory bowel disease. ${ }^{1}$ Inappropriate expression of HLA class II molecules in the crypt epithelium of proximal small intestinal biopsy specimens obtained from affected children has been documented also. ${ }^{2}$ Major histocompatibility complex (MHC) class II products are usually restricted to the cells of the immune system and play a role in antigen presentation and induction of the immune response. Mature enterocytes of the small intestine (but not immature enterocytes) ${ }^{34}$ represent an exception in that they express these molecules physiologically. It has been suggested that the function of MHC class II molecules in the small intestine is related to the maintenance of oral tolerance. ${ }^{56}$

The phenomenon of aberrant MHC products has previously been observed in the epithelium of diseased tissue obtained from patients with classic autoimmune diseases, such as insulin dependent diabetes mellitus and autoimmune thyroid disorders. ' It has also been repeatedly described in the colonic mucosal epithelium from patients affected by inflammatory bowel disease and jejunal crypts in coeliac disease. ${ }^{8-10}$ All of these epithelia are known to be physiologically devoid of class II molecules.

Experimental evidence has shown, in the context of autoimmunity, that when epithelial cells acquire class II products they are able to act as accessory antigen presenting cells, and so become capable of presenting autoantigens to CD4 activated T lymphocytes in a major histocompatibility complex restricted fashion. "It has been suggested that this phenomenon may play a relevant role in the final autodestruction of epithelial cells. ${ }^{12}$ There are indications that a similar mechanism could operate in inflammatory bowel disease. ${ }^{6}$

In classical enteropathies such as coeliac disease the mucosal abnormality is generally confined to the small intestine and the colonic mucosa is spared. In children with severe protracted diarrhoea and autoimmune enteropathy, however, it has been repeatedly observed that the diarrhoea responds only partially to dietary treatment and that blood and mucus can be present in the stools. These latter findings suggest that an inflammatory process affecting the colon could be associated with the enteropathy and that a more generalised intestinal disorder occurs in these patients.

The aim of this study, therefore, was to ascertain the possible presence of a colitis in these children and, if confirmed, to define better the histological and immunological characteristics, with particular reference to features of immune activation such as inappropriate class II molecule expression on the epithelium, as already detected in the small intestine.

\section{Patients and methods}

\section{PATIENTS}

Eight children (seven boys and one girl) with protracted diarrhoea of more than 2 weeks duration (range 2 months to 2 years) and aged 5 months to 2 years on presentation, were found to have circulating small intestinal enterocyte autoantibodies detected by indirect immunofluorescence on at least two occasions. In six of the eight there was a titre of $1 / 8-1 / 128$. They underwent peroral jejunal biopsy (Watson Paediatric Capsule) and were found to have: (a) an enteropathy with a variable degree of villous atrophy (Table I), lymphomononuclear infiltration of the lamina propria, but no increase in the number of intraepithelial lymphocytes and in six of eight crypt hyperplasia; (b) aberrant class II molecule expression detected in all jejunal biopsy specimens in the crypt epithelium.

Clinical details are shown in Table II. Patients $1,2,3$, and 7 have been described previously.' 
TABLE I Histological appearances of large and small intestinal biopsy specimens from autoimmune patients on presentation and during relapses

\begin{tabular}{lll}
\hline Patient & $\begin{array}{l}\text { Colonic histology } \\
\text { and age }\end{array}$ & $\begin{array}{l}\text { fejunal histology } \\
\text { and age }\end{array}$ \\
\hline 1 & 6 months: grade 2 & 5 months: SSVA \\
10 months: PVA & 8 months: SVA \\
2 & 1 year: grade 3 & 1 year: SVA \\
& 3 years: grade 2 & years: normal \\
& 5 years: grade 2 & 2 years: patchy PVA \\
3 & 2 years: patchy grade 1 & 2 years: severe PVA \\
4 & 2 years: grade 1 & 9 months: normal \\
5 & 9 months: grade 1 & 19 months: PVA \\
6 & 19 months: grade 2 & 7 months: PVA \\
7 & 7 months: grade 1 & 16 months: patchy PVA \\
8 & 5 months: grade 1 & 2 years: PVA \\
\hline
\end{tabular}

*See text for grading. SSVA = severe, subtotal villous atrophy; PVA = partial villous atrophy; SVA = subtotal villous atrophy.

All eight patients presented with severe protracted diarrhoea which had started between 2 weeks and 1 year of age. They were all anorexic and lethargic. The weight was below the third centile for age in seven children, but one (patient 6) had been on parenteral nutrition from 2 weeks of age and his weight was in the normal range. The length of six children was normal, but the height of two of those who presented aged 2 years was below the third centile. The erythrocyte sedimentation rate was raised in the three in whom it was measured on presentation. In only one patient (patient 7) was there a personal and family history of initial acute, possibly infectious, diarrhoea. He presented first with vomiting; diarrhoea ensued within 48 hours and his father suffered a similar illness. No stool samples were taken until several days after the onset of diarrhoea, when the child's stool was examined for viral and bacterial pathogens, but none were detected. Three patients (patients 1,4 , and 5) had life threatening watery diarrhoea which was secretory in origin (stool sodium $83-116 \mathrm{mmol} / \mathrm{l}$ ) on presentation to hospital. Patient 1 passed up to 21 of stool per 24 hours when he weighed $5 \mathrm{~kg}$ at 7 to 8 months of age. Patients 1,4 , and 6 had fat globules detected in stool but faecal fat content was not formally measured in any child. Patient 5 had a gastrochisis and required a small intestinal resection soon after birth. $\mathrm{He}$ was treated with parenteral nutrition from 2 weeks of age as he was not gaining weight and on this treatment had satisfactory weight gain. Plasma albumin was below $30 \mathrm{~g} / 1$ in patients $1(23 \mathrm{~g} / \mathrm{l}), 3$ $(13 \mathrm{~g} / \mathrm{l}), 6(27 \mathrm{~g} / \mathrm{l})$, and $7(17 \mathrm{~g} / \mathrm{l})$ on presentation. Patient 3 had concomitant nephrotic syndrome.

Seven patients had other circulating autoantibodies and three of these had autoimmune disorders (Table II). Patient 3 developed an interstitial nephropathy with tubular membrane autoantibodies which resulted in end stage renal failure, and he underwent renal transplant. Patient 4 had a Coomb's positive haemolytic anaemia. Patient 7 presented at 3 months of age with psychomotor retardation and he was found to be hypothyroid with thyroglobulin and microsomal antibodies (at the same time as he presented with diarrhoea). Patient 6 had biliary hypoplasia which was possibly autoimmune in nature in that bile duct autoantibodies were detected.

Six children also had a family history of possible autoimmune disease. Patients 1,6 , and 8 had first degree relatives with histories of protracted diarrhoea, and this was most severe in patient 8 who had four siblings who had died of diarrhoeal disorders. The brother of patient 2 had insulin dependent diabetes, the father of patient 7 had vitiligo, and the mother of patient 5 was thyrotoxic.

All children were initially treated with an oligoantigenic diet which consisted of a cow's milk, egg, and gluten free regime. Comminuted chicken meat (Cow and Gate) was used as cow's milk substitute in five patients; Pregestimil, a casein hydrolysate (Mead Johnson, UK) to two; and Pepdite, a peptide formulation (Scientific Hospital Supplies Ltd, UK) in one. Despite improvement in the symptoms while on the diet, a variable degree of diarrhoea persisted in all eight patients. In four of the eight there was blood and mucus in their stool. In all patients stool culture and electron microscopy were negative. Total colonoscopy was performed in all eight patients with an Olympus PCF10 colonoscope. In patients 5 and 7, colonoscopy preceded jejunal biopsy. At least two biopsy specimens

TABLE II Clinical features and family history of patients with autoimmune enteropathy $(E c A b+)$

\begin{tabular}{|c|c|c|c|c|c|c|}
\hline Patient & $\begin{array}{l}\text { Age at } \\
\text { presentation }\end{array}$ & Sex & $\begin{array}{l}\text { Age at } \\
\text { onset }\end{array}$ & $\begin{array}{l}\text { Other } \\
\text { autoimmune } \\
\text { diseases }\end{array}$ & $\begin{array}{l}\text { Family history of } \\
\text { gastrointestinal/ } \\
\text { autoimmune diseases }\end{array}$ & $\begin{array}{l}\text { Gut autoantibody } \\
\text { titre }\left(E_{c} A b\right) \text {. } \\
\text { Other autoantibodies }\end{array}$ \\
\hline 1 & 5 mths & $M$ & 3 mths & - & $\begin{array}{l}\text { Uncle: protracted } \\
\text { diarrhoea of infancy }\end{array}$ & $\begin{array}{l}\mathrm{EcAb} 1 / 128 \\
\mathrm{BB}+\mathrm{ve}\end{array}$ \\
\hline 2 & $8 \mathrm{mths}$ & $\mathbf{F}$ & $5 \mathrm{mths}$ & - & $\begin{array}{l}\text { Grandmother: } \\
\text { thyrotoxicosis } \\
\text { Brother: IDDM }\end{array}$ & $\begin{array}{l}\text { EcAb } 1 / 64 \\
\text { PCA weak+ve }\end{array}$ \\
\hline 3 & $2 \mathrm{yrs}$ & M & $1 \mathrm{yr}$ & $\begin{array}{l}\text { Interstitial } \\
\text { nephropathy } \\
\text { Chronic hepatitis }\end{array}$ & - & $\begin{array}{l}\text { EcAb } 1 / 64 \\
\text { PCA 1/80, ANA } 1 / 1280 \\
\text { DNA } 1 / 320, \text { TBM } 1 / 80\end{array}$ \\
\hline 4 & $2 \mathrm{yrs}$ & M & $4 \mathrm{mths}$ & $\begin{array}{l}\text { Haemolytic } \\
\text { Anaemia }\end{array}$ & - & $\begin{array}{l}\text { EcAb+ve } \\
\text { Coomb's+ve }\end{array}$ \\
\hline 5 & 9 mths & $M$ & 2 wks & & $\begin{array}{l}\text { Mother: } \\
\text { thyrotoxicosis }\end{array}$ & $\begin{array}{l}\text { EcAb 1/8 } \\
\text { TBM 1/40 }\end{array}$ \\
\hline 6 & $7 \mathrm{mths}$ & M & $1 \mathrm{mth}$ & $\begin{array}{l}\text { Biliary } \\
\text { hypoplasia }\end{array}$ & $\begin{array}{l}\text { Siblings: protracted } \\
\text { diarrhoea and biliary } \\
\text { hypoplasia }\end{array}$ & $\begin{array}{l}\text { EcAb } 1 / 8 \\
\text { Bile duct + ve } \\
\text { AMA } 1 / 20\end{array}$ \\
\hline 7 & $5 \mathrm{mths}$ & M & $3 \mathrm{mths}$ & Hypothyroidism & Father: vitiligo & $\begin{array}{l}\text { EcAb 1/64 } \\
\text { TgHa 1/5000 } \\
\text { McHa 1/1 } 600 \\
\text { SMA 1/10 }\end{array}$ \\
\hline 8 & 2 yrs & $\mathbf{M}$ & $1 \mathrm{mth}$ & & $\begin{array}{l}4 \text { siblings died from } \\
\text { diarrhoeal diseases }\end{array}$ & EcAb 1/8 \\
\hline
\end{tabular}

$\mathrm{BB}=$ brush border rat kidney antibodies; $\mathrm{SMA}=$ smooth muscle antibodies; $\mathrm{TBM}=$ tubular basement membrane antibodies; PCA=parietal cell antibodies; $\mathrm{McHa}=$ microsomal antibodies; ANA=antinuclear antibodies; DNA=native DNA antibodies; AMA = antimitochondrial antibodies; $\mathrm{TgHa}=$ thyroglobulin antibodies 
were taken from the following regions of the colon: caecum, ascending colon, transverse colon, descending colon, sigmoid colon, and rectum in all patients.

All the children remained on a hypoallergenic diet and treatment with salazopyrine $(50 \mathrm{mg} / \mathrm{kg} /$ day) was given for colitis. In those in whom symptoms persisted, immunosuppressive treatment was begun with prednisolone alone $(2 \mathrm{mg} / \mathrm{kg} /$ day, gradually reduced, when possible, to a maintenance dose $0.5 \mathrm{mg} / \mathrm{kg}$, alternate days) or in combination with azathioprine $(2 \mathrm{mg} / \mathrm{kg} /$ day) if the symptoms were still present. Further treatment with cyclophosphamide ( $3 \mathrm{mg} / \mathrm{kg} / \mathrm{day}$ ) was given if no response to prednisolone and azathioprine was achieved. The response to treatment was measured clinically by observing stool consistency and output and recording weight gain, and by endoscopy and biopsy when indicated.

Detailed immunological studies included: total white cell count and differential, value of serum immunoglobulins (Ig) and IgG subclasses, absolute number and \% of $\mathrm{T}$ cell subsets, $\mathrm{T}$ cell function (by passive haemagglutination stimulation), neutrophil mobility and function, and measurement of the alternative complement pathway activity (by yeast opsonisation).

\section{CONTROLS}

Six children were used as control subjects. Jejunal biopsy and colonoscopy were undertaken only where both investigations were clinically indicated. The control subjects comprised five girls and one boy, aged from 3 weeks to 10 years on presentation, all of whom had had diarrhoea for more than 2 weeks (range 3 weeks to 2 years). Their serum was negative for enterocyte autoantibodies or other known autoantibodies apart from reticulin antibody in one. Stool culture, microscopy, and electron microscopy studies were also negative. They all underwent proximal small intestinal mucosal biopsy. In five the intestinal mucosa was abnormal. One child with reticulin antibodies had subtotal villous atrophy that resolved on a gluten free diet and a diagnosis of possible coeliac disease was made. Three children with partial villous atrophy had idiopathic protracted diarrhoea, and one child with a mucosal infiltration of eosinophils had an eosinophilic gastroenteropathy. The child with histologically normal mucosa had congenital chloridorrhoea. An inappropriate class II expression was detected in the crypts of the patient with subtotal villous atrophy and two of those with partial villous atrophy, but in the other three subjects this abnormality was not observed.

\section{ANTIENTEROCYTE ANTIBODY ASSAY}

An indirect immunofluorescence method was used to detect enterocyte autoantibodies using human blood group $\mathbf{O}$ duodenum, obtained from patients undergoing Whipple's procedure.' Briefly, $4 \mu \mathrm{m}$ cryostat sections were incubated with undiluted patient's serum for $\mathbf{3 0}$ minutes at room temperature. A subsequent incubation with fluorescein isothiocyanate conjugated rabbit antihuman IgG (DAKO) followed. After each incubation the sections were washed with phosphate buffered saline for 10 minutes. The slides were then mounted and the reading was performed by two independent readers using a Zeiss type III microscope.

\section{COLONIC BIOPSY SPECIMEN STUDIES}

At least two separate specimens from adjacent areas of the caecum; ascending, transverse, descending, and sigmoid colon; and rectum were processed. One specimen from each area was fixed in Bouin's solution and examined using a conventional haematoxylin and eosin stain, and another was snap frozen for subsequent immunofluorescence studies.

As with the immunological data, the interpretation of the histological results was performed blind by two independent observers. The patient and control biopsy specimens were pooled, coded, and examined in random order. The histological appearance of the mucosa was graded from 1 to 3 according to the severity of inflammation of the lamina propria using the following criteria:

Grade 1: mild inflammatory infiltrate with no other apparent pathological changes present in the surrounding tissue.

Grade 2: moderate inflammatory infiltrate with patchy goblet cell depletion with or without minor crypt distortion.

Grade 3: heavy inflammatory infiltrate with marked goblet cell depletion or crypt abscesses, or both, and crypt dysplasia.

Cryostat sections from snap frozen colonic biopsy specimens were stained for HLA class I molecules and class II subregion products (HLA-DR, DP, DQ) using indirect immunofluorescence and the corresponding monoclonal antibodies (Table III), as previously reported. ${ }^{2}$ At least two different levels of the tissue block were examined.

Immunoperoxidase staining was performed on sections from two patients and three control subjects using monoclonal antibodies to $\mathrm{CD} 3$, $\mathrm{CD} 8$, and CD4 lymphocyte subpopulations, and positive intraepithelial lymphocytes were counted per 1000 epithelial cells.

\section{Results}

\section{IMMUNOLOGY}

There were no severe immunodeficiencies. One child had no detectable serum IgA and four of the six investigated had an abnormality of at least one IgG subclass (Table IV). T cell subsets were abnormal in three patients (Table IV). Two children had reduced neutrophil mobility. One child (patient 2) had increased numbers of circulating activated cells $(71 \% v$ an expected $17 \%$ of DR + cells)

The results of HLA tissue typing are given in Table IV.

\section{COLONOSCOPY}

At colonoscopy, the colon was macroscopically abnormal throughout its length in the eight index patients, with loss of the normal vascular 
TABLE III Mouse monoclonal antibodies used for immunofluorescence study

\begin{tabular}{|c|c|c|c|}
\hline Clone & Specificity & Class & Source \\
\hline Mid 3 & $\begin{array}{l}\text { HLA-DR } \\
\text { (non-polymorphic) }\end{array}$ & $\mathrm{IgG}_{1}$ & G Guarnotta and B Lydyard \\
\hline $\begin{array}{l}\text { DA6.164 } \\
\text { TU22 } \\
\text { B7/21 } \\
\text { W6/32 } \\
\text { P11 H }\end{array}$ & $\begin{array}{l}\text { HLA-DR locus specific } \\
\text { HLA-DQ/locus } \\
\text { DP locus } \\
\text { HLA-A, B, C } \\
\text { Mouse thyroglobulin } \\
\text { (as control) }\end{array}$ & $\begin{array}{l}\mathrm{IgG}_{1} \\
\mathrm{IgG}_{1} \\
\mathrm{IgG}_{1} \\
\mathrm{IgG}_{2 \mathrm{a}} \\
\mathrm{IgG}_{1}\end{array}$ & $\begin{array}{l}\text { K Guy and V Van Heningen } \\
\text { A Ziegler } \\
\text { W and J Bodmer } \\
\text { W and J Bodmer } \\
\text { G Guarnotta and P Lydyard }\end{array}$ \\
\hline $\begin{array}{l}\mathrm{UCHT}_{1}(\mathrm{CD} 3) \\
\mathrm{UCHT}_{4}(\mathrm{CD} 8) \\
\text { Leu 3a (CD4) }\end{array}$ & $\begin{array}{l}\text { Pan T } \\
\text { Cytotoxic-suppressor } \\
\text { Helper/inducer }\end{array}$ & $\begin{array}{l}\mathrm{IgG}_{1} \\
\mathrm{IgG}_{1} \\
\mathrm{IgG}_{1}\end{array}$ & $\begin{array}{l}\text { PC L Beverly } \\
\text { PC L Beverly } \\
\text { Becton-Dickinson }\end{array}$ \\
\hline
\end{tabular}

predominantly consisted of lymphocytes and plasma cells with scattered eosinophils and neutrophils (Fig 2 (A) and (B)). In two patients (grade II and III colitis) there was patchy depletion of goblet cells and, in one the microscopic findings were more severe; there was distortion of the crypt architecture and crypt abscesses were seen (grade III).

Different biopsy specimens from different regions of the colon in individual patients showed only minor variations of not more than

\begin{tabular}{|c|c|c|c|c|c|c|c|}
\hline Patient & Total IgG & $I g G I$ & $\operatorname{IgG2}$ & $I g G 3$ & $I g G 4$ & $\begin{array}{l}T \text { cell subset ratios } \\
C D 4: C D 8\end{array}$ & HLA tissue typing \\
\hline 1 & $\mathbf{N}$ & $\mathbf{N}$ & Undetectable & $\mathbf{N}$ & Undetectable & $5: 1$ & \multirow{8}{*}{$\begin{array}{l}\text { A1, 28; B8, 51; Cw7, } 0 \\
\text { DR2, 3(British) } \\
\text { A1, 24; B39; Cw7, } 0 \\
\text { DR 6, 7 (British) } \\
\text { A3, 26; B7, 49; Cw6, 7 } \\
\text { DR2, 5 (British) } \\
\text { - } 1 \text { 2; B44, w57 } \\
\text { Cw4, 6; DR 4, } 7 \\
\text { (British } \\
\text { A23, 26: B35, 49; } \\
\text { Cw4, 7; DR 2, 3 } \\
\text { (Arabic) } \\
\text { A3, 23; B14, } 35 \\
\text { (British) } \\
\text { - }\end{array}$} \\
\hline 2 & $\mathbf{N}$ & $\mathbf{N}$ & $\begin{array}{l}4 \\
(58-174)^{\star}\end{array}$ & $\mathbf{N}$ & $\mathrm{N}$ & $\mathrm{N}$ & \\
\hline 3 & $\begin{array}{l}38 \\
(48-138)\end{array}$ & - & - & - & - & - & \\
\hline 4 & $\mathbf{N}$ & $\mathbf{N}$ & $\mathbf{N}$ & & $\mathbf{N}$ & $1: 1$ & \\
\hline 5 & $\mathbf{N}$ & $\begin{array}{l}256 \\
(333-724)\end{array}$ & $\begin{array}{l}32 \\
(40-188)\end{array}$ & $\begin{array}{l}106 \\
(14 \cdot 5-36 \cdot 5)\end{array}$ & $\begin{array}{l}40 \\
(5 \cdot 5-31 \cdot 5)\end{array}$ & $\mathrm{N}$ & \\
\hline 6 & $\mathrm{~N}$ & $\mathrm{~N}$ & $\begin{array}{l}16 \\
(35-87)\end{array}$ & $\mathrm{N}$ & $\begin{array}{l}1 \cdot 5 \\
(4 \cdot 8-17 \cdot 8)\end{array}$ & $\mathrm{N}$ & \\
\hline 7 & $\begin{array}{l}24 \\
(25-108)\end{array}$ & - & - & - & - & $\mathrm{N}$ & \\
\hline 8 & $\mathrm{~N}$ & $\mathrm{~N}$ & $\mathbf{N}$ & $\mathrm{N}$ & $\mathbf{N}$ & $1: 2$ & \\
\hline
\end{tabular}

^Normal values for age are given in parenthesis; $\mathrm{N}=$ normal; $-=$ not performed.

pattern (Fig 1 (A) and (B)), mucosal friability, and frequent contact bleeding. In addition, in three patients the mucosa showed patchy areas of erythema and in two others there was visible ulceration. In the six control children, the colonic mucosa was endoscopically normal.

\section{HISTOLOGY}

Morphological alterations were present in all eight patients but varied from a diffuse mild colitis with only an increase in inflammatory cells to a severe colitis with goblet cell depletion, crypt dysplasia, and crypt abscess formation. In no cases were granuloma seen. In six children there was a mild (grade I) colitis with an infiltration of inflammatory cells in the lamina propria which

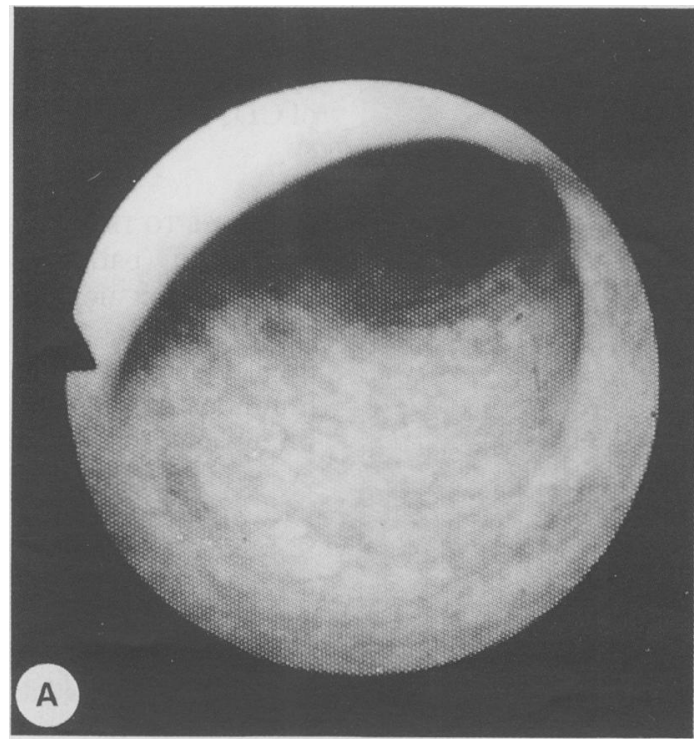

one grade. No abnormalities were seen in the control colon specimens except in one subject where melanosis coli was detected. There was no discordance in the histological findings between the two independent observers.

\section{IN SITU IMMUNOLOGICAL STUDIES}

\section{HLA class I expression on colon epithelial cells} In both patient and control biopsy specimens, the expression of HLA-A, B, C molecules was detected with approximately the same intensity. The staining pattern was not homogenous and areas of stronger reactivity in the crypt epithelium could be seen compared with those of the surface epithelial cells.

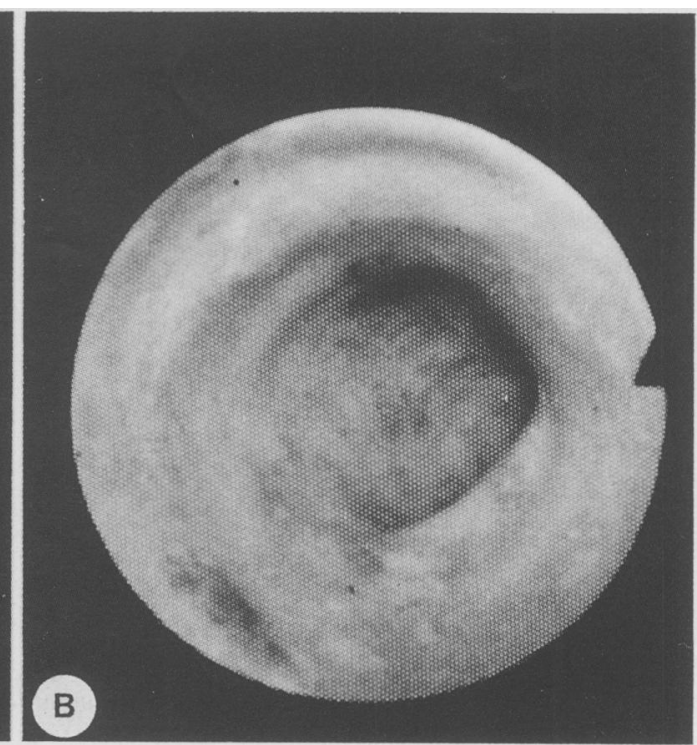

Figure 1: Macroscopic appearance of the colon at colonoscopy. (A) Mild colitis with loss of the normal vascular pattern and occasional areas of erythema. (B) More severe changes with marked erythema. 

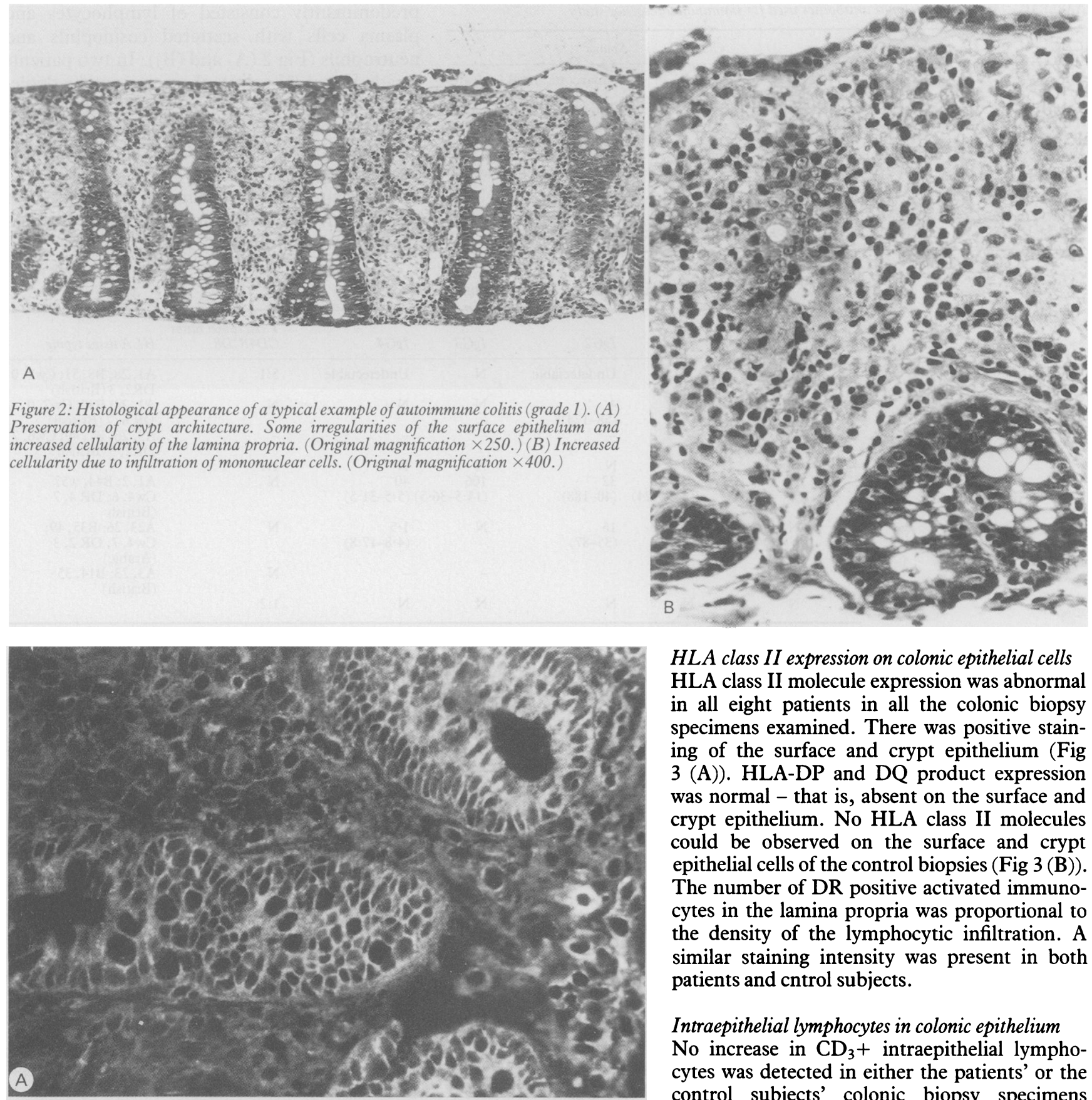

HLA class II expression on colonic epithelial cells HLA class II molecule expression was abnormal in all eight patients in all the colonic biopsy specimens examined. There was positive staining of the surface and crypt epithelium (Fig 3 (A)). HLA-DP and DQ product expression was normal - that is, absent on the surface and crypt epithelium. No HLA class II molecules could be observed on the surface and crypt epithelial cells of the control biopsies (Fig $3(\mathrm{~B})$ ). The number of DR positive activated immunocytes in the lamina propria was proportional to the density of the lymphocytic infiltration. A similar staining intensity was present in both patients and cntrol subjects.

\section{Intraepithelial lymphocytes in colonic epithelium}

No increase in $\mathrm{CD}_{3}+$ intraepithelial lymphocytes was detected in either the patients' or the control subjects' colonic biopsy specimens (range $0.5-1 \cdot 2$ per 100 epithelial cells). $\mathrm{CD}_{8}$ positive intraepithelial lymphocyte counts ranged from $1 \cdot 1$ to 2 lymphocytes per 100 epithelial cells, and it was clear that a proportion of $\mathrm{CD}_{8}+$ cells were also $\mathrm{CD}_{3}+$.

\section{RESPONSE TO TREATMENT}

One child (patient 7) remained on an oligoantigenic diet alone, the diarrhoea resolved, and repeated colonoscopies were not clinically indicated. The other seven children required immunosuppressive treatment, initially with prednisolone alone. Patient 2 has relapsed whenever this has been stopped. Total colonoscopy with multiple biopsy specimens has been performed three times and has shown moderately active non-specific colitis at times of relapse, two and four years after presentation. She has remained on a low dose of oral prednisolone since. In four patients $(1,4,5$, and 8$)$ the small intestinal enteropathy was more severe than the

Figure 3: Colonic mucosa stained by indirect immunofluorescence for $H L A-D R$ expression. ( $A$ Aberrant expression of HLA-DR by crypts in autoimmune colitis. (B) Normal colon showing positive staining of cells in lamina propria and negative crypts. 
colitis and they required more aggressive immunosuppresion for the enteropathy than for the colitis. In patient 1 the secretory diarrhoea stopped only when azathioprine was given. Patient 4 improved when cyclophosphamide was given as well as azathioprine, but eventually died at the age of 4 years. In patient 5 , the colitis preceded the enteropathy. It initially responded to prednisolone but recurred after a few months, finally improving with the addition of azathioprine. Patients 3, 6, and 8 also responded to azathioprine. All children continued to take prednisolone and a restricted diet. Patient 3, however, later developed chronic renal failure and required a renal transplant and further immunosuppressive treatment for this. Of the seven surviving children, six are now thriving with their weight in the normal range and are growing at a normal rate. The seventh child (patient 8) has been lost to follow up. Patient 5 (who had a small intestinal resection) continues to require his diet to be supplemented with parenteral nutrition.

\section{Discussion}

Our findings show that children with protracted diarrhoea, circulating enterocyte autoantibodies, and an enteropathy, who may also present with blood and mucus in their stools, have histological evidence of an accompanying colitis. These observations suggest the presence of a novel generalised gut syndrome, affecting both the small intestine and the colonic mucosa, with common immunomorphological features. It seems that an autoimmune predisposition also occurs in these patients in that autoimmune disorders or other autoantibodies, or both, are present in most. However, possibly because of the small number of patients investigated, HLA tissue typing did not consistently document the presence of haplotypes generally observed in autoimmune disease and there was not an obvious association with systemic immunodeficiency.

The existence of a clear 'generalised gut disorder' affecting both the small intestine and the colon is an unusual finding. With the exception of Crohn's disease, which may involve any part of the gastrointestinal tract, there have been only isolated reports describing the simultaneous involvement of the small and large bowel. A colitis has been found in a few adults who also have coeliac disease, suggesting a possible association between the two clinical conditions. ${ }^{13}$ Furthermore, it is known that diffuse damage of both small intestine and colon sometimes occurs in subjects with scleroderma or other connective tissue disorders. ${ }^{14}$ In children, however, reports concerning the existence of protracted enterocolitis have been even more scarce and so far have not led to the recognition of a specific clinical entity. Colonic inflammation severe enough to cause rectal bleeding has been described in two children with coeliac disease. ${ }^{15}$ In a more recent series, Sanderson $e t$ al $^{16}$ reported the presence of a microscopic colitis in $5 \%$ of children undergoing colonoscopy for protracted diarrhoea. Four of the six patients had abnormal small bowel morphology. Interestingly, one of these had an autoimmune enteropathy and another (in whom enterocyte autoantibodies were not sought) had thyrotoxicosis.

It seems that the group of children presented here with protracted diarrhoea of infancy, is affected by an enterocolitic process and that the severity of the enteropathy usually overrides that of the colitis. The colitis, however, heightens the severity of the diarrhoea by reducing the 'salvage' capacity of the colon and in addition is responsible for the presence of blood and mucus. Whether both regions of the gut are simultaneously affected or one is affected before the other is usually not clear. It is, however, of interest that in an experimental animal model small bowel extracts injected into rats were able to induce a colitis in the same animal, and the antiserum obtained from the immunised rats gave an immunofluorescent reaction on the small intestinal epithelia similar to that described in children with autoimmune protracted diarrhoea and enterocyte autoantibodies. ${ }^{17}$ This experimental evidence taken together with our clinical observations described here suggest a common pathogenetic process affecting both the small intestine and the colon.

In the present study, the inappropriate DR expression in the crypt epithelium and the presence of various degrees of lymphocyte infiltration in the lamina propria of the colonic biopsy specimens of children affected with protracted diarrhoea, parallel similar observations previously described in the crypt epithelium of the jejunum ${ }^{2}$ and indicate that the same immunological mechanism is possibly responsible for both the enteropathy and the colonopathy. The detection of an aberrant HLA class II expression in the small intestine and in colonic crypts is reminiscent of a similar event already described in gland epithelium obtained from patients with classical autoimmune diseases. ${ }^{7}$ Thus, there is the possibility that this phenomenon, which has already been shown to play an important role in initiating or maintaining the epithelial cell destruction in classical autoimmune diseases (via autoantigen presentation to CD4+ 'activated' $\mathrm{T}$ lymphocytes), could also be responsible for the enterocyte and colonocyte damage.

However, at least within the gut, the detection of inappropriate DR expression in the epithelium is not always seen in a strict context of autoimmunity. It has clearly been described in mucosa obtained from colon affected by carcinoma ${ }^{18}$ Crohn's disease, and ulcerative colitis, ${ }^{8}$ and in the crypts of small intestinal biopsy specimens from patients with coeliac disease. ${ }^{9}$ In these diseases, no circulating enterocyte autoantibodies have been shown and the existence of a clear autoimmune mechanism is still controversial. Recently, however, a colonic tissue bound IgG has been specifically found in colonic biopsy specimens from patients with ulcerative colitis $^{1920}$ and an antibody dependent cell mediated cytotoxicity to epithelial targets has also been detected in the lymphocytes in the lamina propria of the colon of these patients but not of controls. ${ }^{21}$ Consequently, the possibility that autoimmune mechanisms may play a role in inflammatory bowel disease still exists, although it is certainly far from being established. 
In our patients, the evidence that the inappropriate class II expression in the colonic epithelium and the lymphocytic infiltration in the lamina propria are clearly due to an autoimmune phenomenon is circumstantial, though the presence of circulating enterocyte autoantibodies points in this direction. Unlike circulating enterocyte autoantibodies, colonic antibodies could not be reproducibly detected in our hands. In any case, there is considerable doubt about their importance as their presence in inflammatory bowel disease could not be correlated with the disease activity, its duration, or extent of the disease pattern. ${ }^{2122}$ At the present time the autoimmune nature of the colitis cannot be fully substantiated, although a cell mediated rather than a humoral immune mechanism may be responsible for the present form of colitis, as has been suggested in other cases of inflammatory bowel disease by some authors. ${ }^{21} 22$

Finally, there are analogies between the gut disorder of the children described here and Crohn's disease: (a) diarrhoea with blood and mucus is seen in both diseases; (b) both conditions may affect the small intestine and the colon with variable severity; (c) there are similar features of immune activation, such as inappropriate class II expression in the epithelium and lymphocytic infiltration in the lamina propria; (d) immunosuppressive treatment can be beneficial.

It will thus be important to follow up these patients for a long time to ascertain whether the colonic involvement represents an early unusual presentation of the better known overt inflammatory bowel diseases or alternatively is a separate pathological entity from that affecting the small intestine.

SH was in receipt of a Training Research Fellowship from Action Research for the Crippled Child. We gratefully acknowledge generous financial support during this study from Crohn's in Childhood Research Appeal (CICRA), and technical assistance from Mr G Anderson. We thank Dr Marion Malone (Department from Mr G Anderson. We thank Dr Marion Malone (Department
1 Mirakian R, Richardson A, Milla PJ, et al. Protracted diarrhoea of infancy: evidence in support of an autoimmune variant. $B M \mathcal{F}$ 1986; 293: 1132-6.

2 Mirakian R, Hill S, Richardson A, Milla PJ, Walker-Smith JA, Bottazzo GF. HLA product expression and lymphocyte subpopulation in jejunum biopsies of children with idiosubpopulation in jejunum biopsies of children with idiopathic protracted diarrhoea and

3 Scott H, Solheim BG, Brandtzaeg P, Thorsby E. HLA-DR like antigens in the epithelium of the human intestine. Scand F Immunol 1980; 12 : 77-82.

4 Selby WS, Janossy G, Goldstein G, Jewell DP. T lymphocytes in human intestinal mucosa: the distribution and relationship to MHC-derived antigens. Clin Exp Immunol 1981; 44: 453-8.

5 Bland PW, Warren LG. Antigen presentation by epithelia cells of the rat small intestine. II. Selective induction of suppressor T cells. Immunology 1986; 58: 9-14.

6 Meyer L, Shlien R. Evidence for function of Ia molecules on gut epithelial cells in man. $\mathcal{F}$ Exp Med 1987; 166: 1471-83.

7 Bottazzo GF, Todd I, Mirakian R, Belfiore A, Pujol-Borrell R. Organ-specific Autoimmunity: a 1986 overview. Immunol Organ-specific Autoim

8 Selby WS, Janossy G, Mason DY, Jewell DP. Expression of HLA-DR antigens by colonic epithelium in inflammatory bowel disease. Clin Exp Immunol 1983; 53: 614-8.

9 Arnaud-Battandier F, Cerf-Bensussan N, Amsellem R, Schmidtz J. Increased HLA-DR expression by enterocytes in children with coeliac disease. Gastroenterology 1986; 91 : 1206-12.

10 Brandtzaeg P, Sollid LM, Thrane PS, et al. Lymphoepithelial interactions in the mucosal immune system. Gut 1988; 29 : $1116-30$.

11 Londei M, Lamb JR, Bottazzo GF, Feldmann M. Epithelial cells expressing aberrant MHC Class II determinants can cells expressing aberrant MHC Class II determinants can present

12 Bottazzo GF, Pujol-Borrel R, Hanafusa T, Feldmann M. Role of aberrant HLA-DR expression and antigen presentation in induction of endocrine autoimmunity. Lancet 1983; ii $1115-9$.

13 Kitits G, Holmes GFT, Cooper BT, Thompson H, Allan RN Association of coeliac disease and inflammatory bowe disease. Gut 1980; 21 : 636-41.

14 Peachey RDG, Creamer B, Pierre TW, et al. Sclerodematous involvement of the stomach and the small and large bowel. Gut 1969; 10: 285-92.

15 Ansaldi N, Santin B, Dell'Orso D, Lears P. Proctosigmoiditis and coeliac disease. Arch Dis Child 1978; 53: 645-8.

16 Sanderson IR, Boyle S, Williams CB, Walker-Smith JA. Histological abnormalities in biopsies from macroscopically normal colonoscopies. Arch Dis Child 1986; 61: 27+7.

17 Correani A, Pallone F, Accinni L, Iannoni L, Natali P. Correani A, Pallone F, Accinni L, Iannoni $L$, Natali $P$.
Chronic experimental colitis in rats induced by a small bowel antigen. Ital f Gastroenterol 1978; 10: 41-4.

18 Darr AS, Fuggle SV, Ting A, Fabri JW. Anomalous expression of HLA-DR antigens on human colorectal cancer cells f Immunol 1982; 128: 447-52.

19 Das KM, Dubin R, Nagai T. Isolation and characterisation of colonic tissue-bound antibodies from patients with idiopathic ulcerative colitis. PNAS (USA) 1978; 75: +528-32

20 Nagai T, Das KM. Detection of colonic antigen(s) in tissues from ulcerative colitis using purified colitis colon tissuebound IgG (CCA-IgG). Gastroenterology 1981; 81: +63-70.

21 Targan SR, Kagnoff MF, Brogan MD, Shanan F. Immunologic mechanisms in intestinal diseases. Ann Intern Med logic mechanisms

22 MacDermott RP, Stenson WF. Alterations of the immune system in ulcerative colitis and Crohn's disease. Ad Immunol 1988; 42: 285-328. 